\title{
Feeding value of azolla (Azolla pinnata) in goats
}

\author{
G Samanta, Y Tamang
}

Bidhan Chandra Krishi Viswavidyalaya Mohanpur, Nadia, West Bengal, India

Azolla, a small aquatic fern is distributed throughout the tropical, subtropical and temperate fresh water ecosystems. In the present study sun-dried azolla was evaluated for feeding of Black Bengal goats. Forty Black Bengal male kids (5.43 - $7.15 \mathrm{~kg}$ body weight) were randomly distributed to 4 equal groups and fed standard kid grower rations containing sun-dried azolla at $0,10,20$ and $50 \%$ levels replacing concentrate mixture on equi-weight basis. The concentrate mixture composed of maize, 50 ; groundnut cake, 15 ; rice polish, 16 ; wheat bran, 16 ; mineral mixture, 2 ; salt, 1 ; and vitamin $A, B_{2}$ and $D_{3}$, 0.30 part respectively. The kids were offered $150 \mathrm{~g}$ concentrate mixture in the morning followed by paragrass ad lib. Growth study was carried out for 90 days and at the end a metabolic trial was conducted. On termination of growth study, carcass characteristics were also studied in the different groups of animals. The chemical composition of sun-dried azolla on dry matter basis showed that it contains dry matter, $90.1 \%$; organic matter, $79.7 \%$; crude protein, $15.4 \%$; crude fibre, $14.1 \%$; ether extract, $2.7 \%$; nitrogen free extract, $47.4 \%$; total ash, $20.4 \%$; hemicellulose, $15.6 \%$; cellulose, $6.8 \%$; lignin, $17.5 \%$; silica, $16.0 \%$; calcium, 1.54 ; phosphorus, 0.35 . Kids fed with $50 \%$ azolla showed profuse diarrhoea and became sick. This group was discarded. The dry matter consumption, feed efficiency and body weight gain in different groups were comparable, indicating that azolla was palatable. Significantly $(P \leq 0.05)$ lower NFE and cellulose digestibilities were observed in $20 \%$ replacement. Nitrogen, calcium and phosphorus balances were positive in all groups. Carcass characteristics of different groups of animals were also comparable. The DCP and TDN values of sun-dried azolla were 8.7 and $51.8 \%$ respectively. These findings indicated that dried azolla can be incorporated up to $20 \%$ of the concentrate mixture of kids without any adverse effect. 